\begin{tabular}{|c|l|}
\hline Title & Freshwater Bryozoa of Tonle Sap, Cambodia \\
\hline Author(s) & Hirose, Masato; Mawatari, Shunsuke F. \\
\hline Citation & $\begin{array}{l}\text { Zoological Science, 24(6), 630-641 } \\
\text { https://doi.org/40.2108/2s. 24.630 }\end{array}$ \\
\hline Issue Date & 2007-06 \\
\hline Doc URL & http://hdl.handle.net/2115/39622 \\
\hline Rights & (c) Zoological Society of Japan /本文献の公開は著者の意思に基づくものである \\
\hline Type & article \\
\hline File Information & zsj24p630.pdf \\
\hline
\end{tabular}

Instructions for use 


\title{
Freshwater Bryozoa of Tonle Sap, Cambodia
}

\author{
Masato Hirose* and Shunsuke F. Mawatari \\ Division of Biological Sciences, Graduate School of Science, Hokkaido University, \\ N10 W8, Kita-ku, Sapporo, Hokkaido 060-0810, Japan
}

\begin{abstract}
We identified a collection of freshwater bryozoans from Tonle Sap (meaning Tonle Lake), Cambodia, a body of water fed by the Mekong River and characterized by extreme fluctuations in water level between the wet and dry seasons. The collection also included specimens from the moat of Angkor Wat, located at the north end of the lake. We found four phylactolaemate species (Plumatella bombayensis, Plumatella casmiana, Plumatella vorstmani, Hyalinella lendenfeldi) and one ctenostome species (Hislopia cambodgiensis) from the lake, and only a single, additional phylactolaemate species (Plumatella javanica) from the moat. We provide brief descriptions of these species, photographs of colonies for some, and photomicrographs by light and scanning electron microscopy (SEM) of statoblasts. None of the species encountered in this study is endemic to Cambodia, and the wide distributions of the species are possibly related to the dispersability of floatoblasts by birds. We briefly discuss some of the taxonomic problems surrounding Hislopia cambodgiensis.
\end{abstract}

Key words: biodiversity, freshwater Bryozoa, Phylactolaemata, Ctenostomata, Cambodia, Tonle Sap

\section{INTRODUCTION}

Bryozoans are benthic colonial animals, mostly sessile, that form colonies of various morphologies by asexual budding. About 6,000 living species have been described from marine environments (Gordon, 1999), and about 65 species from freshwater (Wood and Wood, 2000; Wood and Okamura, 2005). Modern bryozoans are divided into three classes: Gymnolaemata, Stenolaemata, and Phylactolaemata. Most freshwater bryozoans belong to Class Phylactolaemata, although a few species of the gymnolaemate order Ctenostomata also occur in freshwater.

Phylactolaemates differ from the other classes in several respects, including a U-shaped rather than a circular feeding lophophore. The colonies of most species grow in a branched tubular morphology or as a compact gelatinous mass. Unlike other bryozoans, phylactolaemates form encapsulated, asexually produced dormant bodies called statoblasts. Statoblasts are generally resistant to cooling and drying, and germinate under favorable conditions following an obligate period of dormancy, in response to a variety of environmental cues including changes in water temperature and light (Rogick, 1938, 1941a; Oda, 1959, 1979; Mukai, 1974; Bushnell and Rao, 1974). There are two types of statoblasts; one is a free-floating buoyant statoblast called a "floatoblast", and the other is a sessile statoblast, or "sessoblast." Many species can form both types. The morphological features of statoblasts are the most important diagnostic characters for the identification of phylactolaemate species.

Most of the approximately 260 described species of living ctenostome bryozoans inhabit the sea, but at least 12

\footnotetext{
* Corresponding author. Phone: +81-11-706-3524; Fax : +81-11-746-0862; E-mail: m-hirose@sci.hokudai.ac.jp
}

doi:10.2108/zsj.24.630 species worldwide in the genera Hislopia, Sineportella, Paludicella, Pottsiella, and Victorella are known from freshwater habitats. Hislopia is the most speciose genus of ctenostome bryozoans occurring in freshwater; seven species have been reported worldwide. However, there have been few detailed studies of Hislopia species, and the existing taxonomical information is generally insufficient. For example, Jullien (1880) originally described Hislopia cambodgiensis from the Mekong River, but this species has not been reported since 1916, and the paucity of information in the original description makes it difficult to identify specimens as this species with any certainty.

Freshwater bryozoans were studied in Southeast Asia mostly from the late nineteenth century to the early twentieth century (Jullien, 1880; Kraepelin, 1906; Annandale, 1908, 1910, 1911, 1916a, b, 1919; Vorstman, 1928a, b). Recently, there has been renewed interest in freshwater bryozoans in the region (Wood and Wood, 2000; Wood et al., 2006). However, only one study (Jullien, 1880) has included freshwater bryozoans from Cambodia.

From 2003 to 2005, Japanese and Cambodian scientists (S. Tsukawaki, A. Ohtaka, H. Katakura, T. Kamiya, Y. Hirabuki, S. Endoh, Y. Okumura, S. Sotham, A. Cheoulean) collaborated in research to evaluate mechanisms for sustaining biodiversity in Tonle Sap, Cambodia (S. Tsukawaki, pers. comm.). These biologists collected several freshwater bryozoan species from the lake and from the moat of Angkor Wat. Here we present brief descriptions of these species and discuss the life cycle and ecology of the freshwater bryozoans in Tonle Sap, to the extent permitted by our limited data.

\section{MATERIALS AND METHODS}

\section{Study area}

Tonle Sap $\left(\approx 12^{\circ} 50^{\prime} \mathrm{N}, 104^{\circ} 06^{\prime} \mathrm{E}\right.$; surface elevation $\approx 10-20 \mathrm{~m}$ asl), located in the mid-western part of Cambodia, is the largest 
natural lake in Indochina (Fig. 1). Among all lakes in the world, this lake shows the greatest change in water level between wet and dry seasons. In the dry season (November to April), it is about 3,000 $\mathrm{km}^{2}$ in area and only about $1 \mathrm{~m}$ in maximum depth. In the wet season (May to October) (Fig. 2), the lake is fed by a reverse flow of the Mekong River via the small Tonle Sap River. The area of the

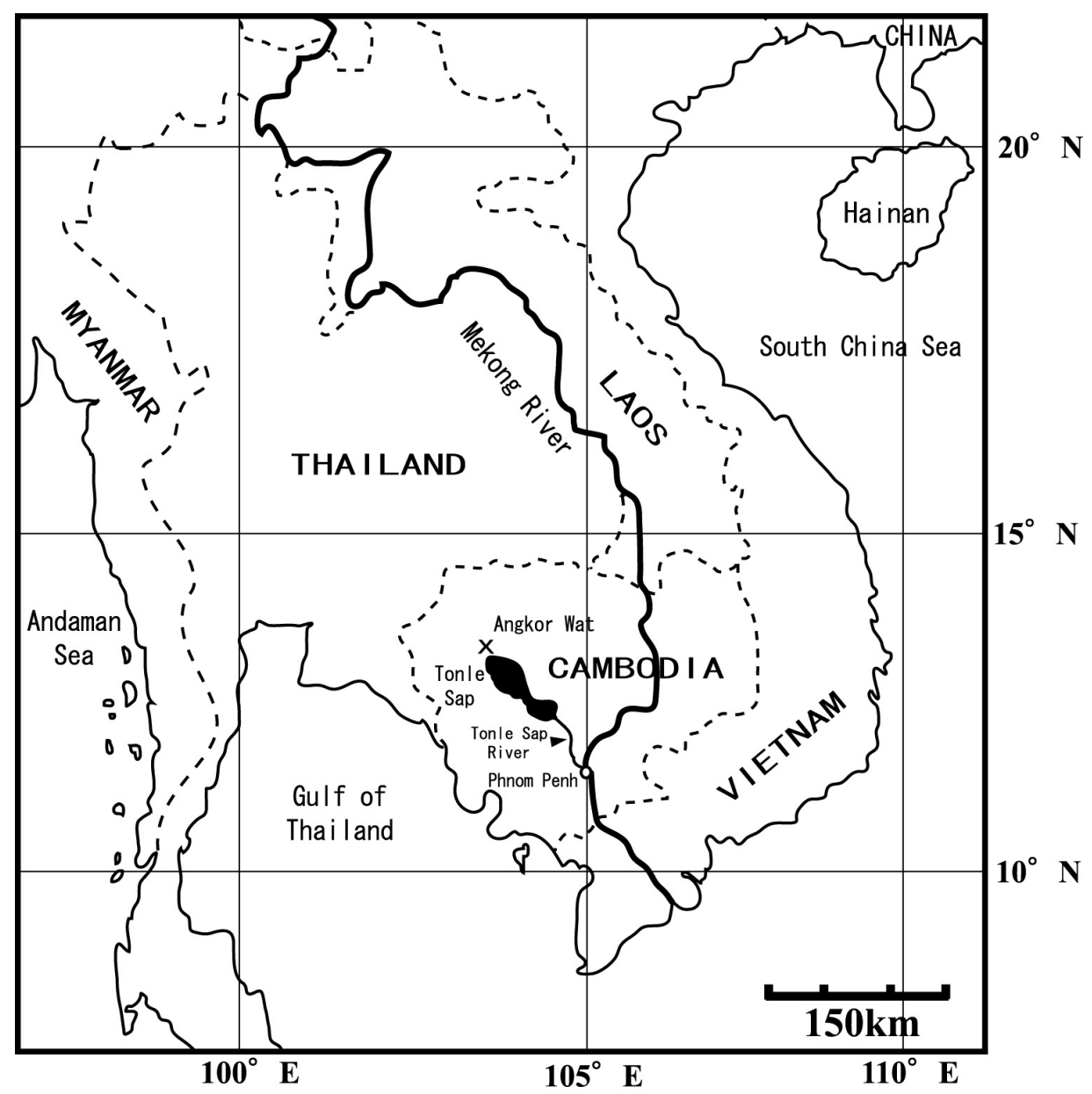

Fig. 1. Map of Southeast Asia showing the location of Tonle Sap in Cambodia and the extent of the lake during the dry season. The Tonle Sap River connects the lake with the Mekong River (heavy line).

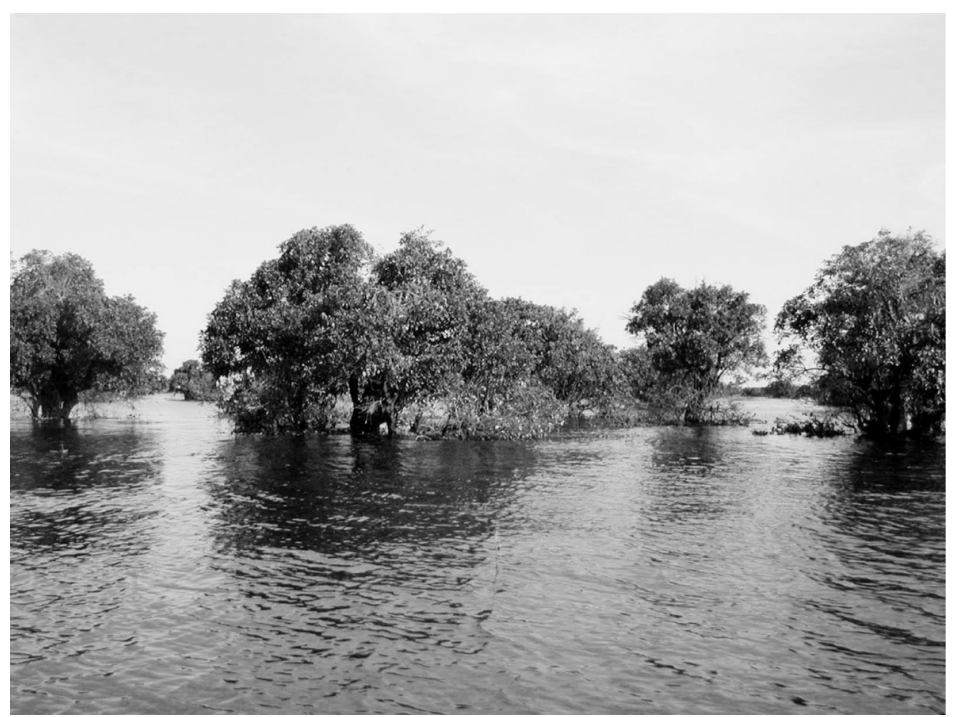

Fig. 2. Photograph of Tonle Sap during the wet season. The bushes shown here are completely emergent during the dry season, when the water level is about $10 \mathrm{~m}$ lower than in the wet season. 
lake increases to about $16,000 \mathrm{~km}^{2}$, over four times that in the dry season, with a maximum change in depth of about $10 \mathrm{~m} \mathrm{(CNMC/}$ NEDECO, 1998). As a consequence of the changes in water level, bushy vegetation around the lake that is submerged in the wet season, and provides a substratum for freshwater bryozoans, dries up in the dry season. Situated in the tropics, Tonle Sap shows little annual variation in temperature; the annual range is about $26-30^{\circ} \mathrm{C}$ (Endoh et al., 2002). At the north end of Tonle Sap is located the ancient temple of Angkor Wat, which is surrounded by a moat about $190 \mathrm{~m}$ across.

\section{Collection and treatment of specimens}

Prof. A. Ohtaka collected bryozoans from the moat of Angkor Wat in 2002 and at two localities in Tonle Sap from 2003-2005; the only substrates on which he found specimens were submerged branches and the roots of water hyacinths. Specimens were initially fixed in $10 \%$ formalin, except for Hislopia specimens collected from the lake in 2005 , which were fixed in $90 \%$ ethanol. Statoblasts were dehydrated with ethanol and HMDS (hexamethyldisilazane), coated with Pd-Pt in a Hitachi E-1030 sputter-coater, and observed with a Hitachi S-2380N scanning electron microscope (SEM) at $15 \mathrm{kV}$ accelerating voltage. Ctenostome bryozoans were dehydrated with butanol, embedded in paraffin, and sectioned at a thickness of 7 $\mu \mathrm{m}$. Sections were stained with hematoxylin-eosin and observed by light microscopy to measure the size of the gizzard and count the number of tentacles.

\section{RESULTS}

In all, we identified six species of freshwater bryozoans, including four species of phylactolaemates and one ctenostome in Tonle Sap and an additional phylactolaemate species in the moat of Angkor Wat.

\section{Taxonomy}

Class PHYLACTOLAEMATA Allman, 1856

Family Plumatellidae Allman, 1856

Genus Plumatella Lamarck, 1816

Plumatella bombayensis Annandale, 1908

(Fig. 3)

Plumatella bombayensis Annandale, 1908, 169-171, Figs. $1,2$.

Plumatella bombayensis: Annandale, 1910, 43, 51-52; Wood and Wood 2000, 424-425, 427, 429; Wood and Okamura, 2005, 52, 84-86, Figs. 22, 49; Wood et al.,
2006, 10-12, Figs. 5, 6, 14-16.

Plumatella longigemmis: Lacourt, 1968, 73, 75 (in part). Plumatella tanganyikae: Annandale, 1911, 225-227, Fig. 44 (in part).

Material examined. A few statoblasts were collected from Baribour Province in the southern part of Tonle Sap, December 2004.

Description. Colony dark brown, with well-chitinized ectocyst (Wood and Okamura, 2005). Floatoblast elongate, with a large fenestra on ventral valve. Annulus especially broad at both ends. Dorsal valve almost flat; fenestra is smaller than on ventral valve. In young sessoblasts, surface of fenestra is reticulate. With age, tubercles appear in each cell of the reticulation, and in mature sessoblasts (Fig. 3A, B) tuberculation almost entirely obscures the reticulation, which is evident only near the annulus (Fig. 3B).

Remarks. Annandale (1908) originally described $P$. bombayensis from Igatpuri, near Bombay, India. Lacourt (1968) regarded $P$. bombayensis as a synonym of $P$. longigemmis. However, compared to $P$. longigemmis, the floatoblast of $P$. bombayensis has a much wider annulus on the ventral valve, a smaller dorsal fenestra, and a different microstructure on their fenestrae (lightly tuberculate on dorsal valve and strongly reticulate on ventral in $P$. bombayensis; tuberculate on both valves in $P$. longigemmis).

Distribution. $P$. bombayensis has been reported from throughout southern Asia and at a single, artificially heated site in Belarus (Wood and Okamura, 2005).

\section{Plumatella casmiana Oka, 1907}

(Fig. 4)

Plumatella casmiana Oka, 1907, 121-123, Fig. 3.

Plumatella casmiana: Behning, 1924, 172; Vorstman, 1928a, 7-8, Fig. 5, PI. 1, Fig. 8; Rogick, 1941b, 211-219, PI. 1, Figs. 1-4, PI. 2, Figs. 5-6; 1943, 265-270, Pl. 1, Figs. 1-8; Lacourt, 1968, 52-56, PI. 13, Figs. g-I, PI. 15, Fig. a; Rogick and van der Schalie, 1950, 142-144, Figs. 612; Toriumi, 1955, 76-77, Figs. 1-3; Sebestyen, 1961, 127-131, Figs. 3-8; Wiebach, 1963a, 581-595, Figs. 14; 1963b, 77-78, Abb. 1-5; Bushnell and Wood, 1971, 229-230, Fig. 1; Wood, 1979, 59, 61, 68-69, Pl. 1, Figs.
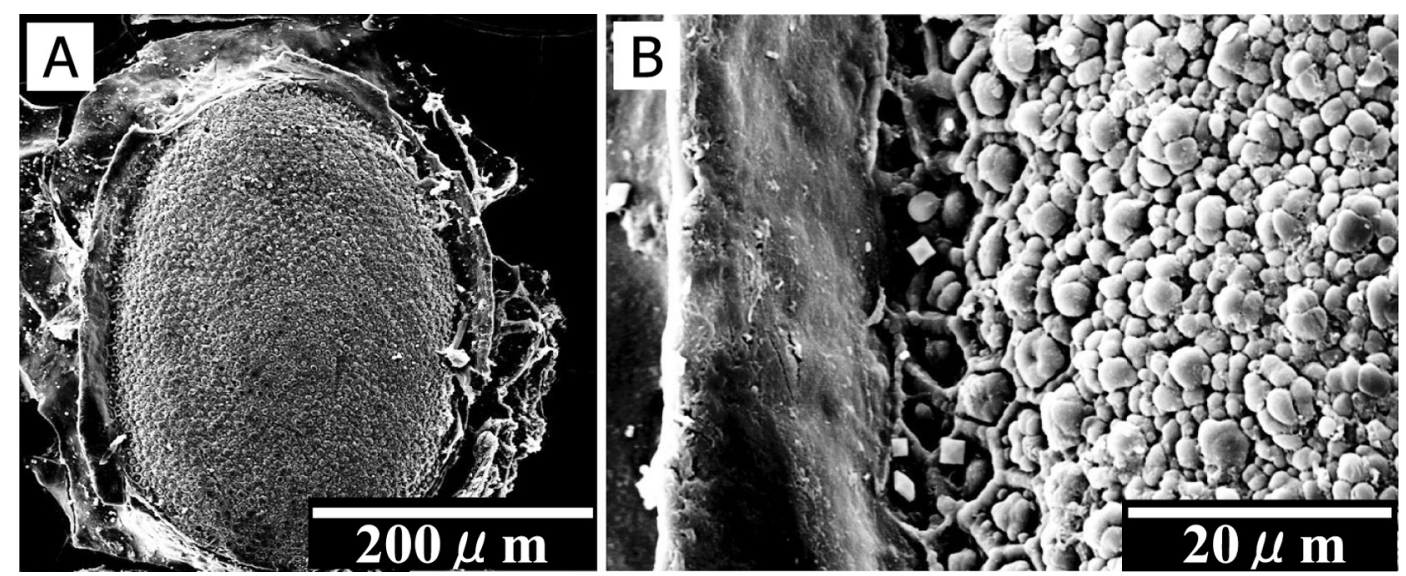

Fig. 3. Plumatella bombayensis Annandale. Scanning electron micrographs; (A) mature sessoblast; (B) enlargement of a mature sessoblast showing that some reticulation remains evident near the annulus. 


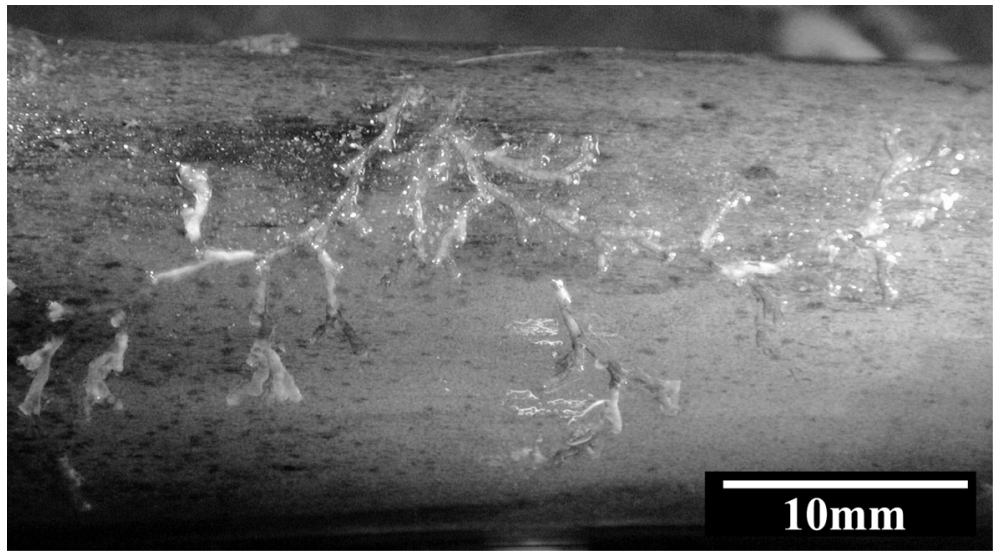

Fig. 4. Plumatella casmiana Oka. Light micrograph showing a portion of a colony attached to the roots of the water hyacinth, Eichhornia crassipes (Mart.).

7-8, PI. 3, Figs. 4-5; 1989, 28-31, Fig. 15; Wood and Wood, 2000, 424, 426; Wood and Okamura, 2005, 46, 78-80, Figs. 16-18, 45-46; Wood et al., 2006, 12, Figs. 11-13.

Plumatella casmiana rossica Abricossoff, 1927, 309.

Plumatella repens Loppens, 1908, 159 (in part); 1910, 145 (in part).

Plumatella repens var. annulata Hozawa and Toriumi, 1940, 428-429, Fig. 3 (A-D); 1941, 236-237, Fig. 3, PI. 14, Fig. 2; Rogick and Brown, 1942, 131-132, PI. 2, Figs. 10, 14,-16, 26, PI. 3, Fig. 30.

Plumatella repens var. casmiana Toriumi, 1941a, 203-204, Fig. 7, PI. 12, Figs. 4-5, PI. 13, Fig. 15; 1942, 209-211, Figs. 1-3.

Plumatella repens var. flabellum type casmiana Toriumi, 1941b, 418-419, Figs. 5-7.

Plumatella philippinensis Lacourt, 1948, 231-232, Figs. 37 (in part).

Plumatella annulata Lacourt, 1955, 88, PI. 5 (bottom center and bottom right).

Material examined. Specimens were collected from the northern part of Tonle Sap in November 2003. These included a few small, brownish, translucent colonies found on roots of the water hyacinth, Eichhornia crassipes (Mart.) Solms. Statoblasts were not observed.

Description. Colony light brown and often fouled. Colony varies in form from having zooids in branched uniserial series (Fig. 4) to having zooids crowded in a compact mass; compact colonies sometimes assume a honeycomb-like shape (Hozawa and Toriumi, 1940; Bushnell and Wood, 1971). Tentacle number about 24. Plumatella casmiana produces two types of free floatoblasts: the usual type of plumatellid floatoblast (capsuled floatoblast) with well a developed periblast, and a type (leptoblast) lacking the internal capsule. The leptoblast has a very narrow annulus and germinates immediately after release from the colony. The capsuled floatoblast has weak tubercles on surface of fenestra; these are sometimes slight, with the surface almost smooth. The sessoblast has a wide annulus and the surface of the capsule is smooth.

Remarks. Oka (1907) originally described $P$. casmiana from Kasumigaura, Japan, and Rogick (1941b, 1943) showed detailed drawings of colony morphology and statoblasts from North America. Lacourt (1948) regarded $P$. casmiana as a synonym of $P$. philippinensis on the basis of floatoblast morphology. However, the floatoblasts and leptoblasts of these two species differ in features of the periblast and the capsule. The weakly tuberculate surface of the capsulated floatoblast is diagnostic for $P$. casmiana.

Distribution. This is one of the most common and widely distributed species worldwide (Bushnell, 1973; Wood et al., 2006).

\section{Plumatella javanica Kraepelin, 1906}

(Figs. 5, 6)

Plumatella javanica Kraepelin, 1906, 143-146, Figs. 1-3.

Plumatella javanica: Annandale, 1910, 42, 50; 1911, 221223; Toriumi, 1952, 267-269; Wiebach, 1964, 12, Figs. 4-8, Taf. 1, Fig. 4, Taf. 2, Figs. 5-7, Taf. 3, Figs. 8-12, Taf. 4, Fig. 13; 1967, 177-178, Taf. 1, 2, Abbs. 1-8; 1970, 356, Taf. 1, Abbs. 4a, 4b, 5a, 5b; Lacourt, 1968 , 72-73, PI. 15, Fig. j; Smith and Wood, 1995, 362-365,

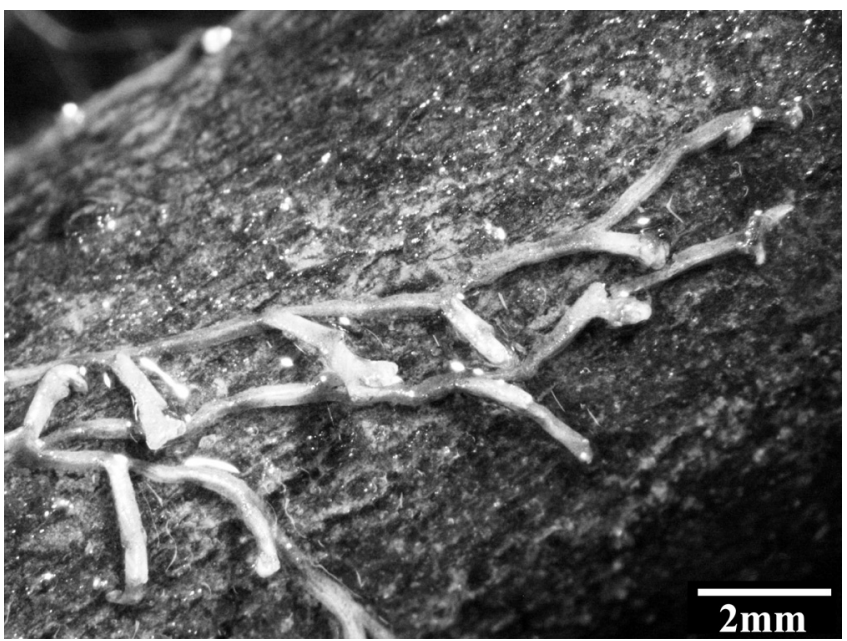

Fig. 5. Plumatella javanica Kraeplin. Light micrograph showing a portion of a colony attached to a branch under the water. 

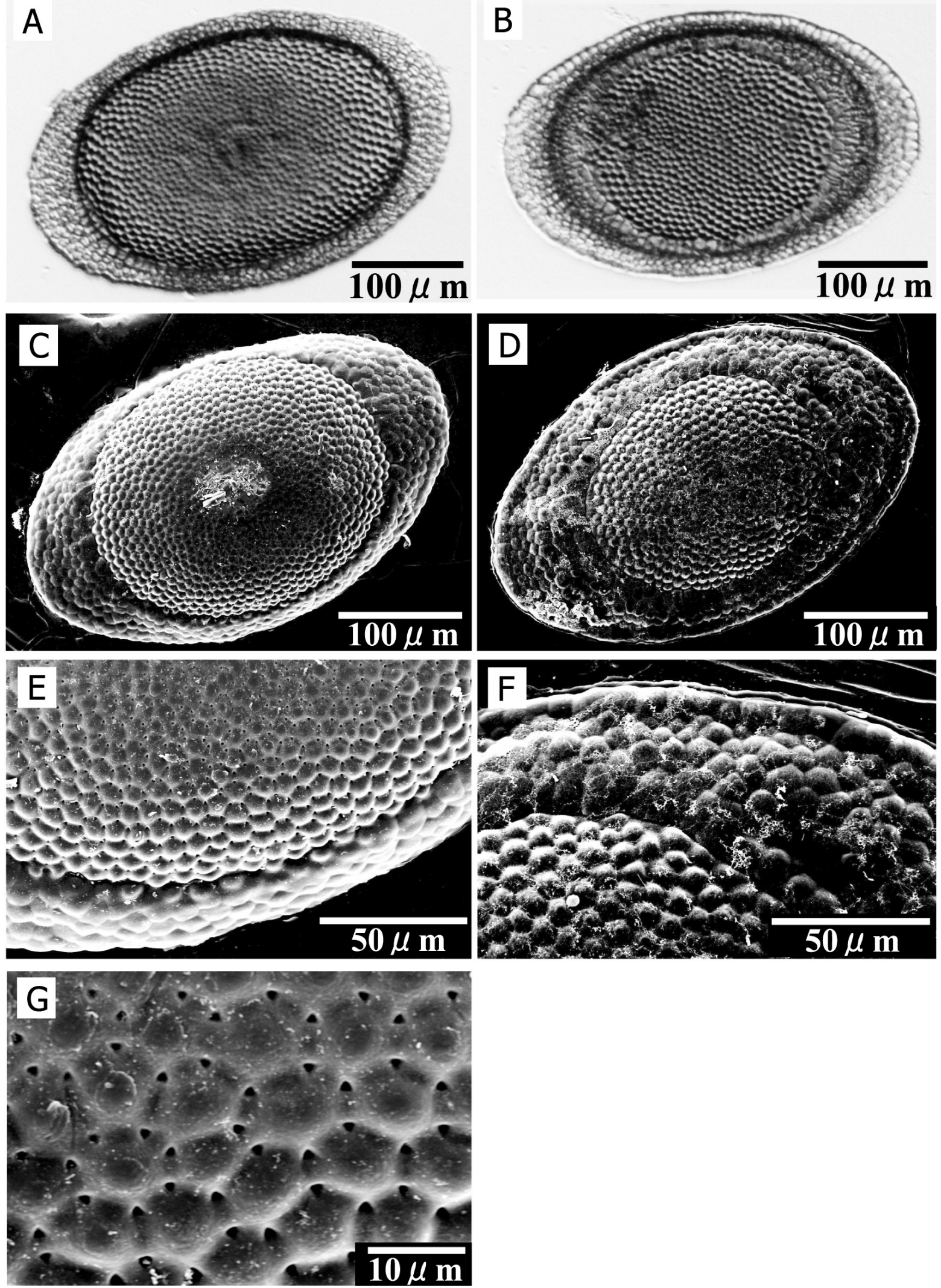

Fig. 6. Plumatella javanica Kraeplin. Photomicrographs of floatoblasts taken by light (A, B) and scanning electron (C-G) microscopy; (A) ventral valve; (B) dorsal valve; (C) ventral valve; (D) dorsal valve; (E) enlargement from (C) showing textures of annulus and fenestrula; (F) enlargement from (D) showing textures of annulus and fenestra; (G), higher magnification enlargement from (C) showing tubercles surrounded by rounded-triangular pores in the angles between tubercles. 
Fig. 1; Wood and Wood, 2000, 423-425, Fig. 1; Wood et al., 2006, 14-15, Figs. 20, 21, 36.

Plumatella emarginata var. javanica Loppens, 1908, 162.

Material examined. Several light-gray colonies with some floatoblasts were collected from the south side of the moat of Angkor Wat in October 2002.

Description. Colony is light brown or light gray, its surface is heavily fouled and encrusted. Colony almost entirely recumbent, with few branches and with a pronounced keel; ends of the branches often rising from the substratum (Fig. 5). Ectocyst of new buds sometimes transparent. Tentacle number about 45. Floatoblast elliptical; large, about $400 \mu \mathrm{m}$ long (Fig. 6A, B). Fenestrae of floatoblast large (Fig. 6A-D); in SEM view, surface entirely covered with minute, rounded tubercles (Fig. 6C-F) rounded-hexagonal in outline, with 58 (average, 6) small rounded-triangular pores in the angles (Fig. 6G). Annulus of floatoblast covered with coarser, more irregular tubercles (Fig. 6F). Floatoblast valves asymmetrical in lateral and transverse views, the ventral valve strongly convex and dorsal valve almost flat. Sessoblast also with tuberculate surface.

Remarks. Kraepelin (1906) originally described $P$. javanica from Indonesia. Previous authors have considered statoblast morphology, colony color, and colony form as important diagnostic characters of this species. Annandale (1911) reported a transparent, glassy ectocyst and a strong raphe, and Smith and Wood (1995) also indicated these characters. However, these features vary ecophenotypically, as with other plumatellid species. Annandale (1911), for example, specifically mentioned variability in the form of zoaria attached to dead wood. Like $P$. javanica, $P$. vorstmani (following description) also has a transparent ectocyst, but the tentacle number in $P$. javanica is almost twice that in $P$. vorstmani, and statoblast size and morphology are different.

Distribution. This species occurs in tropical regions (Bushnell, 1973), including Southeast Asia (Lacourt, 1968; Wood et al., 2006), central Africa (Wiebach, 1964), and the Amazon River in South America (Wiebach, 1967, 1970).

\section{Plumatella vorstmani (Toriumi, 1952)}

(Fig. 7)

Plumatella vorstmani Toriumi, 1952, 268-269, Figs. 1-19.

Plumatella vorstmani: Mukai, 1984, 51-52, Fig. 2; Wood and Wood, 2000, 423, 425, 427, Fig. 5; Wood et al., 2006, 18-19, Figs. 28, 29, 39.

Plumatella javanica: Vorstman, 1928a, 6-7, Fig. 4, PI. 2, Figs. 6-7; 1928b, 163.

Hyalinella vorstmani: Lacourt, 1968, 86-87, PI. 12, Figs. g, i; Wiebach, 1973, 546.

Material examined. Only a few floatoblasts were collected from Baribour Province in the southern part of Tonle Sap in December 2004.

Description. According to Toriumi (1952), Mukai (1984), and Wood et al. (2006), the colony is transparent, almost entirely recumbent; the zooids are never fused with one another; and tentacle number is 20-27. Floatoblast small, about 300-350 $\mu \mathrm{m}$ long by 180-220 $\mu \mathrm{m}$ wide (Fig. 7A-D); symmetrical in lateral view; with tubercles on fenes-

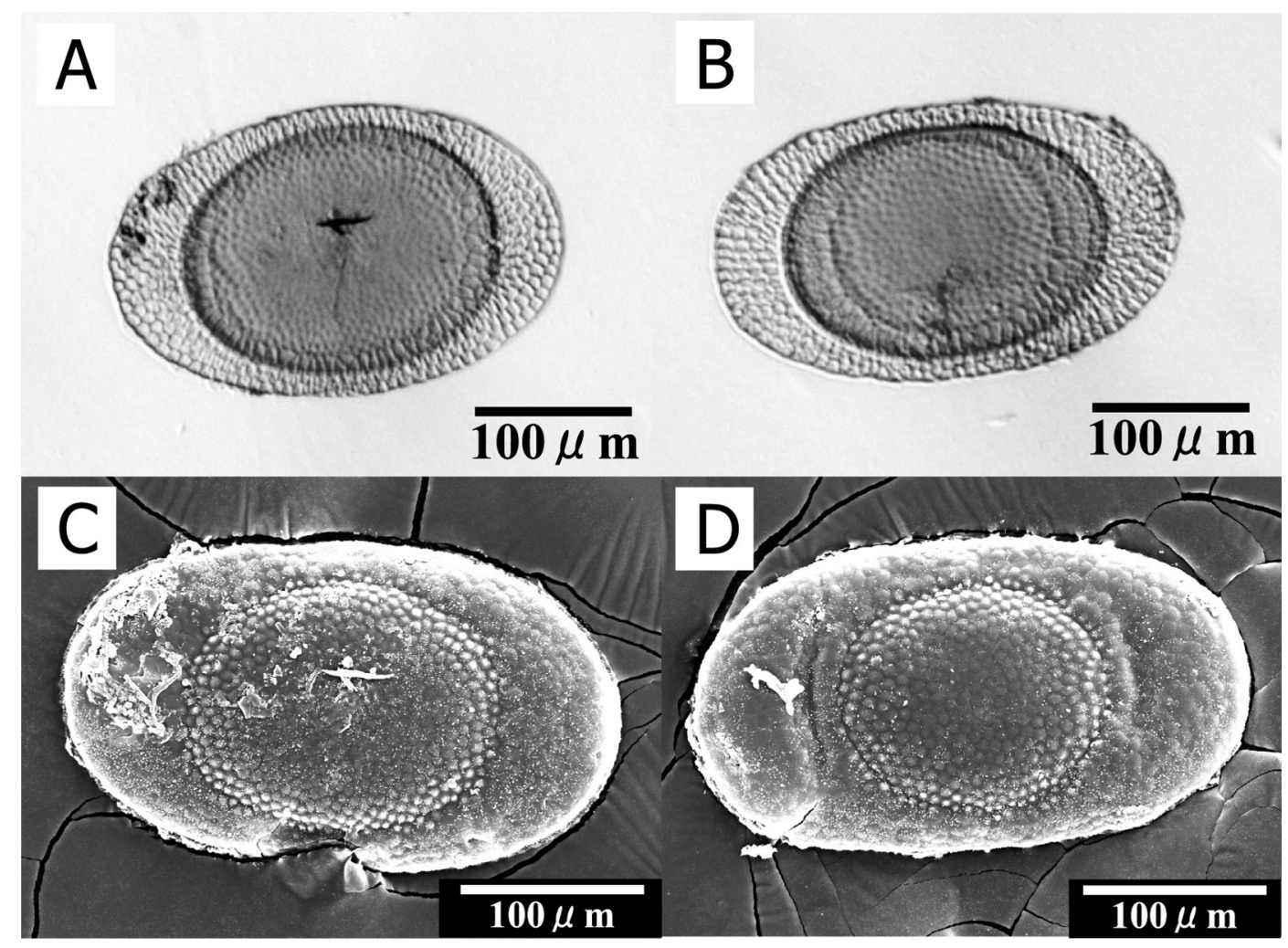

Fig. 7. Plumatella vorstmani (Toriumi). Photomicrographs of floatoblasts taken by light (A, B) and scanning electron (C, D) microscopy; (A) ventral valve; (B) dorsal valve; (C) ventral valve; (D) dorsal valve. 
trae (Fig. 7C, D). Sessoblast with tubercles on surface of capsule and reticulation on annulus (Toriumi, 1952). The sessoblast is shorter than the floatoblast (Toriumi, 1952; Mukai, 1984).

Remarks. Toriumi (1952) recognized $P$. vorstmani as a new species from material that Vorstman (1928a) had reported as $P$. javanica, on the basis of differences from $P$. javanica in tentacle number, floatoblast size, and the surface sculpturing of the sessoblast. Toriumi reported tubercles on the sessoblast. However, Wood and Wood (2000) reexamined specimens that Mukai (1984) had identified as $P$. vorstmani and found the surface of the capsule to be reticulate rather than tuberculate. Wood et al. (2006) reported $P$. vorstmani from many sites in Thailand as having sessoblasts with tuberculate fenestrae, and the features of the floatoblasts are completely compatible with those from Tonle Sap. Uncertainties in the diagnosis of this species are due to equivocal specimens from Japan. Toriumi's and Mukai's phylactolaemate collections contain both tuberculated and reticulated sessoblasts identified as those of $P$. vorstmani (Hirose, unpublished data), and this material possibly includes more than one species.

Lacourt (1968) referred $P$. vorstmani to the genus Hyalinella. However, this species fits better in Plumatella in having sessoblasts and zooids that are loosely attached to one another.

Distribution. Plumatella vorstmani has been reported from Asia (Bushnell, 1973; Wood et al., 2006), Japan (Toriumi, 1952; Mukai, 1984), India (Lacourt, 1968), and Java, Indonesia (Vorstman, 1928a, b).

Hyalinella lendenfeldi (Ridley, 1886)

(Figs. 8, 9)

Lophopus lendenfeldi Ridley, 1886, 62-65, PI. 2, Figs. 1-4. Lophopus lendenfeldi: Whitelegge, 1889, 323; Goddard, 1909, 494; Colledge, 1917, 123.

Australella lendenfeldi Annandale, 1910, 40-41.

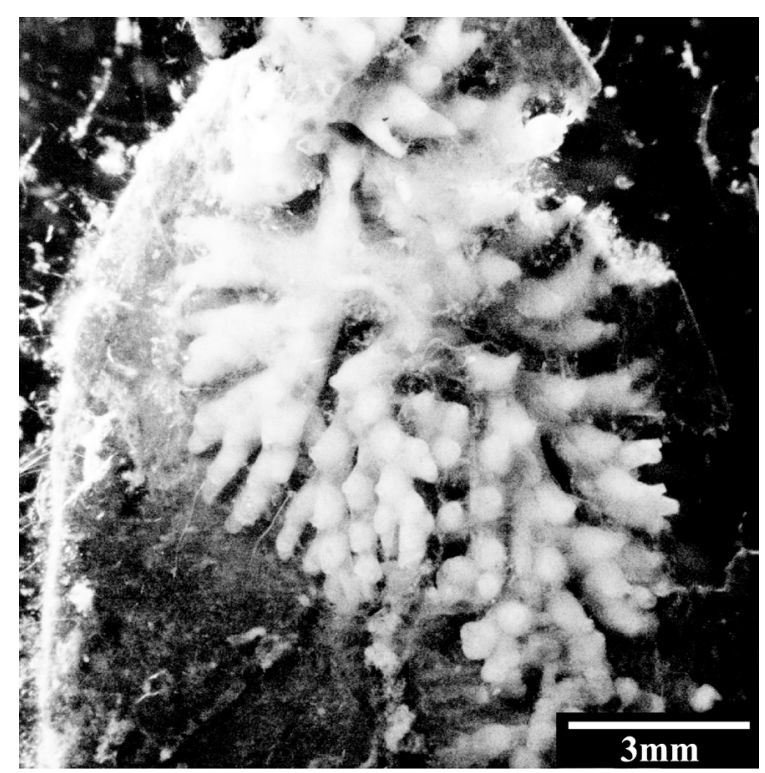

Fig. 8. Hyalinella lendenfeldi (Ridley). Light micrograph showing a colony attached to a submerged tree leaf.
Hyalinella lendenfeldi: Rousselet, 1904, 47 (in list), 49; Loppens, 1908, 162; Annandale, 1919, 94; Hastings, 1929, 301-303, Fig. 1 (A, B); Lacourt, 1968, 96-97, Fig. 6d; Wiebach, 1973, 544; Wood, 1998, 259-260, Figs. 1, 4-7; Wood and Wood, 2000, 424-425; Wood et al., 2006, 7-8, Figs. 2, 9, 10.

Plumatella punctata phase prostrata Vorstman, 1928a, 10, Fig. 7.

Material examined. Three large colonies with many floatoblasts were found on submerged branches of Persicaria hydropiper in the northern part of Tonle Sap, November 2003.

Description. Colony tubular, branched, forming extensive thin patches on the substratum; ectocyst transparent, mature colonies thicker than young ones, the branches surrounded by a gelatinous ectocyst about 1-3 $\mathrm{mm}$ thick (Fig. 8). Hyalinella lendenfeldi produces only floatoblasts (Fig. 9A-D). Floatoblast is oblong, the ends rounded, the margins of the long axis parallel; $670-690 \mu \mathrm{m}$ long by $410-420 \mu \mathrm{m}$ wide, much larger than the floatoblasts of other plumatellid species. Annulus very wide relative to fenestra size. Ventral fenestra about $280 \mu \mathrm{m}$ long by $215 \mu \mathrm{m}$ wide; dorsal fenestra smaller than ventral, about $162 \mu \mathrm{m}$ long by $110 \mu \mathrm{m}$ wide. SEM images show fenestrae of both valves covered with fine, round tubercles (Fig. 9E). Annulus sculptured with closely set tubercles coarser than those of fenestra. Ventral valve convex; dorsal valve flat or concave.

Remarks. Ridley (1886) originally described this species from Australia as Lophopus lendenfeldi. Rousselet (1904) referred it to Hyalinella because of the tubular colony, the soft, gelatinous ectocyst, and the absence of sessoblasts. Annandale (1910) established the genus Australella to which he transferred $H$. lendenfeldi and in which he included another species, $A$. indica. However, this genus is not clearly distinct from Hyalinella (Wood, 1998). Welldeveloped colonies of $H$. lendenfeldi resemble those of Gelatinella toanensis (Hozawa and Toriumi, 1940) reported from East Asia, but the floatoblast of $G$. toanensis is quite different from that of $H$. lendenfeldi in size and in having a spine on the ventral fenestra. Moreover, G. toanensis produces sessoblasts, whereas $H$. lendenfeldi does not.

Distribution. There is a single record of Hyalinella lendenfeldi from Australia (Ridley, 1886); the species has been reported as abundant in Thailand, with records from a lake at Chiang Mai and from Vachiralongkorn Reservoir (Wood et al., 2006).

\section{Class GYMNOLAEMATA Allman, 1856 Order Ctenostomata Busk, 1852 Family Hislopiidae Jullien, 1885 Genus HISLOPIA Carter, 1858 Hislopia cambodgiensis (Jullien, 1880)} (Fig. 10)

Norodonia cambodgiensis Jullien, 1880, 77-78, Figs. 1-3. Norodonia cambodgiensis: Jullien, 1885, 181-182, Figs. 244-245; Anonymous, 1888, 102, Figs. 17-18; Loppens, 1908, 176, Figs. 28-29.

Hislopia cambodgiensis Annandale, 1916a, 34-35, PI. 1, Fig. 8; Hondt, 1983, 19, 21, Fig. 9 (a, c).

Norodonia sinensis Jullien, 1880, 78-79, Figs. 1-3. 

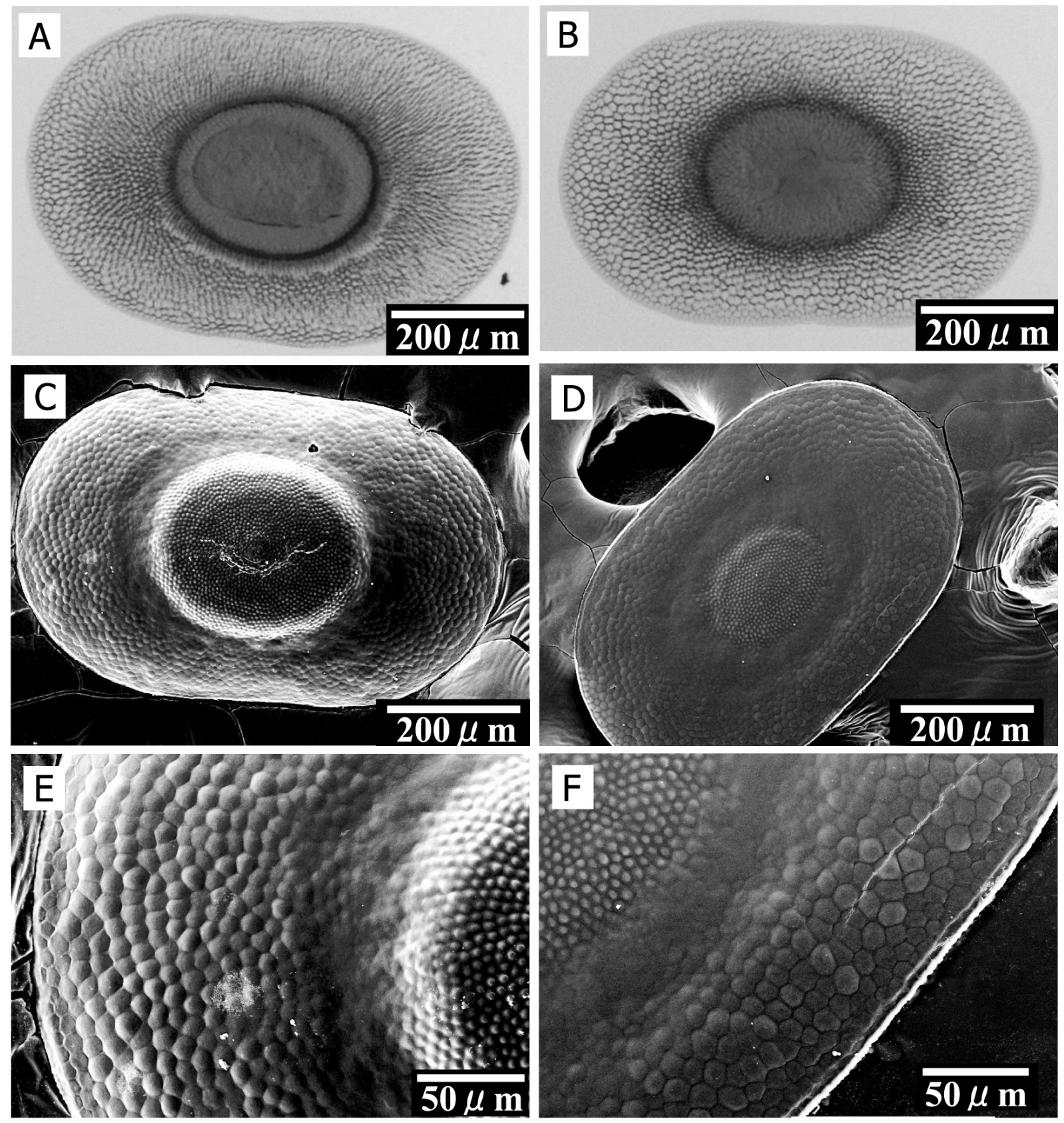

Fig. 9. Hyalinella lendenfeldi (Ridley). Photomicrographs of floatoblasts taken by light (A, B) and scanning electron (C-F) microscopy; (A) ventral valve; (B) dorsal valve; (C) ventral valve; (D) dorsal valve; (E) enlargement from (C) showing textures of annulus and fenestra; (F) enlargement from (D) showing textures of annulus and fenestsra.

Norodonia sinensis: Jullien, 1885, 182, Figs. 246-247;

Anonymous, 1888, 102, Figs. 19-20; Loppens, 1908, 177, Fig. 30.

Hislopia sinensis: Hondt, 1983, 19, 21.

Hislopia lacustris: Annandale, 1911, 202-203 (in part).

Material examined. Eight colonies were collected from the roots of Eichhornia crassipes, northern part of Tonle Sap, November 2003 and December 2005, and from Baribour Province in the southern part, December 2004.

Description. Colony encrusting, spreading broadly on the substratum, the zooids arranged in straight, branching uniserial series; columns of zooids distinct even in crowded colonies (Fig. 10). Zooids light- or dark-yellowish brown, with a transparent ectocyst; oval to almost circular in shape, tapering proximally, about $0.80-0.93 \mathrm{~mm}$ long by $0.60-0.68$ $\mathrm{mm}$ wide, on average 1.18 times as long as wide. Tentacle number about 16 . Orifice is round or rounded-quadrate; oral spines lacking. Gizzard about $150 \mu \mathrm{m}$ long by $150 \mu \mathrm{m}$ wide, with thick lining. Stomach about $280 \mu \mathrm{m}$ long by $140 \mu \mathrm{m}$ wide. The primordium of new autozooidal buds begins from a long, narrow, flattened peduncle that gradually expands before differentiation of the polypide. Ancestrula smaller than astogenetically mature zooids, giving rise to several 

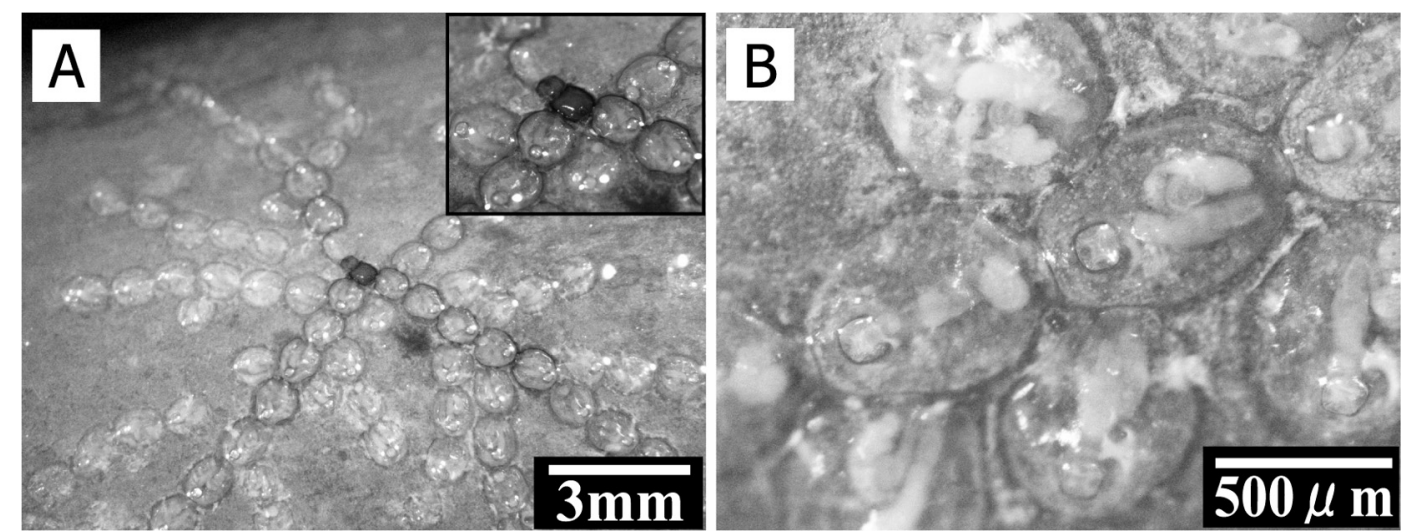

Fig. 10. Hislopia cambodgiensis Jullien. Light micrographs of (A) a colony radiating from an ancestrula; enlargement at upper right shows the ancestrula (dark zooid) and periancestrular zooids; (B) zooids.

daughter zooids that generally each bud two zooids distally, these giving rise to linear series.

Remarks. Jullien (1880) originally described Norodonia cambodgiensis from the Mekong River of northeastern Thailand and also interior Cambodia; however, his description was limited. Annandale (1916a) reported what he identified as Jullien's species from Tai-Hu (Great Lake), China and provided a detailed description; he transferred the species to Hislopia because of similarities in colony and zooid form to Hislopia lacustris, the type species of Hislopia.

Jullien (1880) described a similar species, Hislopia sinensis (as Norodonia sinensis), from the Ngan-Honi Province, southern China. He indicated the key diagnostic character of $H$. sinensis as being the tapering axial keel on the zooidal frontal wall, arising from the proximal lip of the orifice and extending posteriorly for a third to one-half the length of the zooid. However, Jullien observed only dried specimens. The frontal wall of Hislopia is weak and readily shrinks when the colony dries; the central area then appears raised above the gut and other internal organs. The main diagnostic feature of $H$. sinensis is thus perhaps an artifact of drying. Hislopia sinensis is very similar to $H$. cambodgiensis in colony form and other respects, and Annandale (1916a) regarded the two as synonymous. The holotype specimen of $H$. sinensis has been lost.

Annandale (1916a) described from Thailand $H$. malayensis, which is quite similar to our $H$. cambodgiensis. Both species have zooids about $0.85-0.90 \mathrm{~mm}$ long, and $H$. malayensis has about 16 tentacles. The only difference appears to lie in the budding form of new autozooids. The bud of $H$. malayensis is different from that of all other Hislopia species; it has been reported to arise as a slender, blunt-ended, flattened cylinder that reaches almost the full zooid length before expanding at the tip as it gradually assumes the oval shape of the adult zooid (Annandale, 1916a; Hondt, 1983; Wood et al., 2006). However, the form of buds might vary with growth rate or environmental conditions, and the taxonomic reliability of this character is questionable. Considering the original description of $H$. malayensis and the similar distributions of Wood's $H$. malayensis and our $H$. cambodgiensis, these species are possibly synonymous. If this proves to be the case, the latter name will have priority as the earlier description.
Distribution. Hislopia cambodgiensis has been reported from Cambodia; the Mekong River on the border of Cambodia and Siam (Thailand); and Canton, Ngan-Honi, and Tai-Hu (Great Lake), China (Jullien 1880; Annandale, 1916a).

\section{DISCUSSION}

Tonle Sap undergoes great fluctuations in depth and surface area between the wet and dry seasons. Bryozoan colonies that grow on the branches of bushes sunken during the wet season dry out and die (except for their statoblasts) during the dry season. Colonies were also found attached to the water hyacynth (Eichhornia crassipes), plants of which can drift to shore and dry out during the dry season.

In many groups of animals, summarized by Pennak (1989), species living in freshwater can produce resting eggs, hibernacula, or other stages that enable these species to overwinter, or to survive periods of drying, as occur in Tonle Sap. In phylactolaemate bryozoans, statoblasts perform this function. The maximum longevity reported for a phylactolaemate colony (Lophopodella carteri) is about 23 weeks (Rogick, 1935), but colonies developed from dried statoblasts last only about two months (Rogick, 1938, 1941a; Mukai, 1997). However, this is sufficient time for colonies arising from dried statoblasts after the onset of the wet season to produce sexually a generation of colonies that can in turn form statoblasts that will survive the next dry season. Many of the phylactolaemate colonies collected in October (the end of the dry season) and from November to December (early in the wet season) were mature, and some of them also contained abundant statoblasts. The statoblasts of some species (e.g., Hyalinella punctata, Lophopodella carteri, Asajirella gelatinosa) need to dry before they can float (Mukai and Oda, 1980; Mukai, 1982, 1984; Wood and Marsh, 1996).

At temperate latitudes, statoblasts are freed from a dependency on light as a germination stimulus by exposure to low temperature during winter, after which rising water temperatures in spring serve as a germination cue (Oda, 1959, 1979; Mukai, 1974, Bushnell and Rao, 1974). In tropical Tonle Sap, there is little fluctuation in water temperature (annual range $26-30^{\circ} \mathrm{C}$ ), so the environmental cue that triggers the germination of statoblasts may involve drying and 
rehydration, rather than an increase in temperature. In addition, the lake does not entirely dry out during the dry season, and colonies attached to permanently submerged or floating water plants may be able to continually populate the lake by production of larvae and statoblasts.

Hislopia cambodgiensis is a ctenostome bryozoan and does not produce statoblasts. However, species of some other genera of freshwater ctenostomes produce hibernacula, which are masses of cells surrounded by a thick, resistant coat (Pennak, 1989); hibernacula perform essentially the same functions as statoblasts. We did not observe hibernacula in our specimens of Hislopia. Nonetheless, numerous colonies of Hislopia were found in every year of our survey in Tonle Sap (November 2003, December 2004, December 2005). Wood et al. (2006) reported that older zooids of Hislopia malayensis eventually develop thickened walls and form hibernacula. Thus, the production of hibernacula could be one means by which Hislopia cambodgiensis repopulates the lake following the dry season. Alternatively, as with the phylactolaemates, colonies of this species occurring on vegetation that had been exposed during the dry season could have settled there from larvae released by colonies deeper in the lake or dispersed from the Mekong River with the reverse current early in the wet season.

None of the phylactolaemate bryozoan species we identified in Tonle Sap is endemic to Southeast Asia. Hyalinella lendenfeldi, known from Australia, Thailand, and Cambodia, and Hislopia cambodgiensis, known from Southeast Asia and China, have relatively limited distributions. The other four species have broader distributions, including two (Plumatella casmiana and Plumatella javanica) reported from both the paleotropical and the neotropical regions.

These distributions might suggest that the collection we examined contained specimens of only common, widely distributed species and missed individuals of rare or narrowly distributed species. This is not necessarily the case, however. Phylactolaemate bryozoans generally tend to be broadly distributed (Lacourt, 1968; Bushnell, 1973; Wood and Wood, 2000, 2001; Wood and Okamura, 2005), because their floatoblasts provide a mechanism for broad dispersal. Ducks, some amphibians, and some reptiles feeding on the surface of the water are known to ingest floatoblasts, which can remain viable and germinate after passing through the digestive tract (Brown, 1933; Charalambidou et al., 2003). In addition, floatoblasts often attach to feathers of birds (Okamura and Hatton-Ellis, 1995; Freeland, 2001; Wood, 2001). Floatoblasts attached to or ingested by waterfowl can be especially broadly dispersed. The great East Asian-Australian flyway passes through Southeast Asia, and the occurrence of Hyalinella lendenfeldi in Cambodia and Australia is at least consistent with dispersal along this flyway. The central Asian and western Pacific flyways pass close to Southeast Asia, potentially facilitating dispersal to other areas. It is noteworthy the ctenostome bryozoan Hislopia cambodgiensis, which lacks floatoblasts, also has the narrowest distribution of any of the species we found in Tonle Sap; its known distribution is restricted to southern China and the Mekong region of Southeast Asia.

Most taxonomic studies of freshwater bryozoans in Southeast Asia were conducted in the late 19th and early 20th centuries. Geographical coverage of the region by these early studies was limited; some species have been detected only a few times since their original description, and both specimens and redescriptions are few. There were only a few descriptions of new species in tropical and subtropical Asia in the latter half of the 20th century: Plumatella vorstmani from Java (Toriumi, 1952), Swarupella andamanensis from Andaman Island (Rao, 1961), Varunella coronifera and Varunella indorana from India (Wiebach, 1974), and Plumatella ganapati and Hyalinella diwaniensis from Central India (Rao et al., 1985). Recently, Wood et al. (2006) described several new species, including a new Hislopia, after an extensive survey of freshwater bryozoans in Thailand.

Compared to Southeast Asia, freshwater bryozoans have been studied more intensively in Japan (e.g., Oka, 1907; Toriumi, 1941a, 1955; Mukai, 1982, 1984; Oda, 1990; Hirose et al., 2006), where 19 species have been reported. In contrast, only about 30 species have been reported from the much larger area of Southeast Asia (Oriental) (Lacourt, 1968; Bushnell, 1973; Wood and Wood, 2000). This suggests that much remains to be learned about the diversity and distributions of freshwater bryozoans in Southeast Asia, and that more species are likely to be discovered in the region. Reliable taxonomy of both previously described and new species will best be accomplished by both the detailed examination of archival specimens and the use of modern technologies, such as molecular data and SEM observation of the statoblasts.

\section{ACKNOWLEDGMENTS}

This study was funded by a Grant-in-Aid for International Scientific Research from The Japan Society for the Promotion of Science (15405004; Project leader Dr. Shinji Tsukawaki, Kanazawa University, Japan). We thank Professor A. Ohtaka, Hirosaki University, for providing the specimens from the vicinity of Tonle Sap that we examined in this study; Professor H. Katakura, Hokkaido University, for providing pictures of Tonle Sap; Dr. Tim Wood, Wright State University, for critically reviewing the manuscript in great detail and making many crucial suggestions; and Dr. Matthew Dick, Hokkaido University, for discussions and editing.

\section{REFERENCES}

Abricossoff GG (1927) Uber die Susswasser-Bryozoan der USSR. CR Acad Sci Russ 19: 304-312

Annandale N (1908) Three Indian Phylactolaemata. Rec Ind Mus 2: 169-174

Annandale N (1910) Materials for a revision of the phylactolaematous Polyzoa of India. Rec Ind Mus 5: 37-57

Annandale N (1911) Fresh-water Sponges, hydroids and Polyzoa. Fauna Brit India Lond 2 (Bryozoa): 161-251

Annandale N (1916a) Zoological results of a tour in the Far East. Polyzoa Entoprocta and Ctenostomata. Mem Asiat Soc Bengal 6: $13-37$

Annandale N (1916b) Preliminary report on the fauna of the Tale Sap an inland sea of Singora. Journ Nat Hist Soc Siam 2: 90 102

Annandale N (1919) Sponges, Hydrozoa and Polyzoa of Seistan. Rec Ind Mus 18: 83-97

Anonymous (1888) Analitical key to the fresh-water Polyzoa. Amer Micr J 7: 99-102

Behning A (1924) Zur Erforschung der am Flussboden der Wolga lebenden Organismen. Monogr Biol Wolga-Station Naturf Ges Saratov 1: 171-174

Brown CJD (1933) A limnological study of certain fresh-water 
Polyzoa with special reference to their statoblasts. Trans Amer Micr Soc 52: 271-316

Bushnell JH, Wood TS (1971) Honeycomb colonies of Plumatella casmiana OKA (Ectoprocta: Phylactolaemata).Trans Amer Micr Soc 90: 229-231

Bushnell JH (1973) The freshwater Ectoprocta: a zoogeographical discussion. In "Living and fossil Bryozoa" Ed by GP Larwood, Academic Press, London and New York, pp 503-521

Bushnell JH, Rao KS (1974) Dormant of quiescent stages and structures among the Ectoprocta: physical and chemical factors affecting viability and germination of statoblasts. Trans Amer Micr Soc 93: 524-543

Carter HJ (1858) Description of a lacustrine bryozoan allied to Flustra. Ann Nat Hist 1: 169-171

Charalambidou I, Santamaria L, Figuerola J (2003) How far can the freshwater bryozoan Cristatella mucedo disperse in duck guts? Arch Hydrobiol 157: 547-554

CNMC/NEDECO (1998) Natural Resources-based Development Strategy for the Tonle Sap Area, Cambodia (CMB/95/003). Final Report Vol 1, Main Report. Cambodian National Mekong Committee, Phnom Penh

Colledge WR (1917) Lophopus brisbanensis sp. nov. Proc Roy Soc Queensland 29: 123-124

Endoh S, Katakura H, Tsukawaki S, Mita K (2002) Toward a Comprehensive Scientific Study of Tonle Sap Lake (Field Survey Report). Tonle Sap Integrated Research Proposal Committee, Infrastructure Development Institute-Japan, Tokyo (in Japanese)

Freeland JR (2001) Genetic changes within freshwater bryozoan populations suggest temporal gene flow from statoblast banks. Limnol Oceanogr 46: 1121-1129

Goddard EJ (1909) Australian freshwater Polyzoa Part 1. Proc Linn Soc New S Wales 34: 487-496

Gordon DP (1999) Bryozoan diversity in New Zealand and Australia. In "The Other $99 \%$. The Conservation and Biodiversity of Invertebrates" Ed by W Ponder, D Lunney, Transactions of the Royal Zoological Society of New South Wales, Mosman, pp 199-204

Hastings AB (1929) Notes on some little-known phylactolaematous Polyzoa and description of a new species from Tahiti. Ann Mag Nat Hist 10: 300-310

Hirose M, Ikezawa H, Kaneko N, Mawatari SF (2006) Distribution of freshwater bryozoans in Ibaraki Prefecture, central Japan, with reference to water quality. Bull Ibaraki Nat Mus 9: 33-48 (in Japanese with English abstract)

Hondt JL d' (1983) Tabular keys for identification of the Recent ctenostomatous Bryozoa. Mem Inst Oceanogr 14: 19-22

Hozawa S, Toriumi M (1940) Some freshwater Bryozoa found in Manchoukuo. Rep Limnobiol Surv Kwantung Manchoukuo 3: 425-434 (in Japanese)

Hozawa S, Toriumi M (1941) Some freshwater Bryozoa found in Manchoukuo. Sci Rep Tohoku Imp Univ Ser 4 16: 233-241

Jullien J (1880) Description d'un nouveau genre de Bryozoaire Cheilostomien des eaux douces de la Chine et du Cambodge et de deux especes nouvelles. Bull Soc Zool France 5: 77-79

Jullien J (1885) Monographie des Bryozoaires d'eau douce. Bull Soc Zool France 10: 91-207

Kraepelin K (1906) Eine Susswasserbryozoe (Plumatella) aus Java. Mitt Naturhist Mus Hamburg 23: 143-146

Lacourt AW (1948) On two freshwater Bryozoa (Phylactolaemata) from Belgian Congo. Rev Zool Bot Afr 40: 229-234

Lacourt AW (1955) Freshwater Bryozoa (Phylactolaemata) from Curacao, Aruba and Bonaire. Studies on the Fauna of Curacao and other Caribbean Islands 6: 86-88

Lacourt AW (1968) A monograph of the fresh-water Bryozoa - Phylactolaemata. Zool Verh Utigeg Rijksmus Natl Hist Leiden 93: $1-159$

Loppens K (1908) Les Bryozoaires d'eau douce. Ann Biol Lacustre 3: $141-183$
Loppens K (1910) Fauna aquatica europeae. Les Bryozoaires d'eau douce d'Europe. Ann Biol Lacustre 4: 139-161

Mukai H (1974) Germination of the statoblasts of a fresh-water bryozoan, Pectinatella gelatinosa. J Exp Zool 187: 27-40

Mukai H (1982) Notes on the freshwater Bryozoa in Gunma Prefecture (central Japan). Sci Rep Fac Educ Gunma Univ 31: 17-32 (in Japanese with English abstract)

Mukai H (1984) Additions to the freshwater Bryozoa in Gunma Prefecture. Sci Rep Fac Educ Gunma Univ 33: 49-60 (in Japanese with English abstract)

Mukai H (1997) Growth forms of phylactolaemate bryozoan colonies under laboratory culture conditions. Sci Rep Fac Educ Gunma Univ 45: $57-77$

Mukai H, Oda S (1980) Comparative studies on the statoblasts of higher phylactolaemate bryozoans. J Morphol 165: 131-155

Oda S (1959) Germination of the statoblasts in freshwater Bryozoa. Sci rep Tokyo Kyoiku Dai sec B 9: 34-75

Oda S (1979) Germination of the statoblasts of Pectinatella magnifica a freshwater bryozoan. In "Advances in Bryozoology" Ed by GP Larwood, MB Abbott, Academic Press, London, pp 93-112

Oda S (1990) Freshwater bryozoans of Japan. Nihon no Seibutsu 4: 50-57 (in Japanese)

Oka A (1907) Zur Kenntnis der Suesswasser-Bryozoenfauna von Japan. Annot Zool Jap 6: 117-123

Okamura B, Hatton-Ellis T (1995) Population biology of bryozoanscorrelates of sessile, colonial life-histories in fresh-water habitats. Experientia 51: 510-525

Pennak RW (1989) Freshwater Invertebrates of the United States. Protozoa to Mollusca. 3rd Ed, John Wiley and Sons, New York

Rao KS (1961) On a new species of the genus Plumatella, Lamarck (Bryozoa: Ectoprocta) from Andaman Islands. Madhya Bharati 10: $51-53$

Rao KS, Agrawal V, Diwan AP, Shrivastava P (1985) Studies on freshwater Bryozoa 5. Observations on central Indian materials. In "Bryozoa: Ordovician to Recent" Ed by GP Larwood, C Nielsen, Olsen \& Olsen, Fredensborg, Denmark, pp 257-264

Ridley SO (1886) On the Characters of the genus Lophopus, with description of a new species from Australia. J Linn Soc 20: 6164

Rogick MD (1935) Studies on freshwater Bryozoa 3. The development of Lophopodella carteri var. typica. Ohio J Sci 35: 457467

Rogick MD (1938) Studies on fresh-water Bryozoa 7. On the viability of dried statoblast of Lophopodella carteri var. typica. Trans Amer Micr Soc 57: 178-199

Rogick MD (1941a) The resistance of fresh-water bryozoa to desiccation. Biodynamica 3: 369-378

Rogick MD (1941b) Studies on fresh-water Bryozoa 10. The occurrence of Plumatella casmiana in North America. Trans Amer Micr Soc 60: 211-220

Rogick MD (1943) Studies on freshwater Bryozoa 13. Additional Plumatella casmiana data. Trans Amer Micr Soc 62: 265-270

Rogick MD, van der Schalie H (1950) Studies on freshwater Bryozoa 17. Michigan Bryozoa. Ohio J Sci 50: 136-146

Rogick MD, Brown CJD (1942) Studies on fresh-water Bryozoa 12. A collection from various sources. Ann NY Acad Sci 43: 123144

Rousselet CF (1904) On a new fresh-water polyzoon from Rhodesia, Lophopodella thomasi gen. et. sp. nov. J Quekett Micr CI 2: 45-56

Sebestyen O (1961) Occurrence of Plumatella casmiana Oka in Lake Balaton. Ann Inst Biol Hung Acad Sci 28: 125-133

Smith DG, Wood TS (1995) A review of Plumatella javanica Kraepelin 1906 (Ectoprocta) with a reassessment of statoblast morphology. Trop Zool 8: 361-366

Toriumi M (1941a) Studies on freshwater Bryozoa of Japan 1. Sci 
Rep Tohoku Imp Univ Ser 4 16: 193-215

Toriumi M (1941b) Studies on freshwater Bryozoa of Japan 2. Freshwater bryozoa of Tyosen (Korea). Sci Rep Tohoku Imp Univ Ser 4 16: 413-425

Toriumi M (1942) Studies on freshwater Bryozoa of Japan 4. Freshwater Bryozoa of Taiwan (Formosa). Sci Rep Tohoku Imp Univ Ser 4 17: 207-214

Toriumi M (1952) Taxonomical study on fresh-water Bryozoa 4. On Plumatella javanica Kraepelin reported by Vorstman in 1928. Sci Rep Tohoku Imp Univ Ser 4 19: 264-269

Toriumi M (1955) Taxonomical study on fresh-water Bryozoa 10. Plumatella casmiana Oka. Sci Rep Tohoku Imp Univ Ser 4 21: 67-77

Vorstman AG (1928a) Some freshwater Bryozoa at West Java. Treubia 10: 1-14

Vorstman AG (1928b) Freshwater Bryozoa from East Java. Treubia 10: $163-165$

Whitelegge $T$ (1889) List of the marine and freshwater invertebrate fauna of Port Jackson and the neighbourhood. J Roy Soc New $S$ Wales 23: 163-330

Wiebach F (1963a) Studien uber Plumatella casmiana Oka (Bryozoa). Vie et Milieu 14: 579-596

Wiebach F (1963b) Das Moostierchen, Plumatella casmiana. Mikrokosmos 52: 76-79

Wiebach F (1964) Untersuchungen an Susswasser-Bryozoa aus Zentral-afrika. Ann Mus Afr Central Sci Zool 129: 1-42

Wiebach F (1967) Amazonische Moostiere (Bryozoa). Amazoniana 1: $173-187$

Wiebach F (1970) Amazonische Moostiere (Bryozoa) 2. Amazoniana 11: 353-362

Wiebach F (1973) Preliminary notes on a revision of the genus Hyalinella. In "Living and Fossil Bryozoa" Ed by GP Larwood, Academic Press, London and New York, pp 539-547
Wiebach F (1974) Indische Süsswasser - Bryozoen. Limnologische Schr Gewässer Abwäss 53-54: 69-84

Wood TS (1979) Significance of morphological features in Bryozoan statoblasts. In "Advances in Bryozoology" Ed by GP Larwood, MB Abbott, Academic Press, London, pp 59-74

Wood TS (1989) Ectoproct bryozoans of Ohio. Ohio Biol Surv Bull New Ser 8: 1-70

Wood TS (1998) Reappraisal of Australian freshwater bryozoans with two new species of Plumatella (Ectoprocta; Phylactolaemata). Invertebr Taxon 12: 257-272

Wood TS (2001) Freshwater bryozoans: a zoogeographical reassessment. In "Bryozoan Studies 2001" Ed by PN Wyse Jackson, CJ Buttler, ME Spencer Jones, A.A. Balkema Publishers, Lisse, The Netherlands, pp 339-345

Wood TS, Marsh TG (1996) The sinking floatoblasts of Lophopodella carteri (Bryozoa: Phylactolaemata). In "Bryozoans in Space and Time" Ed by DP Gordon, AM Smith, JA Grant-Mackie, NIWA, Wellington, pp 383-389

Wood TS, Wood L (2000) Statoblast morphology in historical specimens of freshwater bryozoans. In "Proceedings of the 11th International Bryozoology Association Conference" Ed by A Herrera-Cubilla, JBC Jackson, Smithsonian Tropical Reserch Institute, Balboa, RP, pp 421-430

Wood TS, Okamura B (2005) A new key to the freshwater bryozoans of Britain, Ireland and continental Europe, with notes on their ecology. Freshwater Biological Association, Cumbria, UK

Wood TS, Anurakpongsatorn P, Mahujchariyawong J (2006) Freshwater bryozoans of Thailand (Ectoprocta and Entoprocta). Nat Hist J Chulalongkorn Univ 6: 81-117

(Received November 24, 2006 / Accepted January 19, 2007) 